\title{
NEW DILEMMAS AND NEW DIRECTIONS IN SOUTH AFRICA AFTER APARTHEID
}

\author{
Interview with Albie Sachs \\ Interview by Stefaan Anrys \\ (first published in Dutch in MO* Magazine on 14 October 2016) \\ Translation by David Chan
}

On 3 October 2016, Sachs, who collects honorary doctorates and other titles as if they were panini stickers, visited Ghent University for the third Mandela Lecture organised by the Africa Platform of the Ghent University Association, and moderated by Prof. Eva Brems. This interview was conducted on that occasion.

'Since the attempt on my life, I see everything as rose-tinted', laughs the man who survived an attack, abolished the death penalty and was close to the ANC leadership. 'If I were to become pessimistic about South Africa, people would really get scared, they'd say: Oh, even Albie doesn't like it anymore '(laughs).

In I988 Albie Sachs was viciously attacked, losing his right arm and the sight of one eye. He was living in exile in Mozambique at the time, as South Africa suffered under the Apartheid regime. Sachs was one of the prominent freedom fighters, but survived the assassination attempt and eventually became an important member of the ANC, one of the many authors of the Constitution of the new South Africa. He was also invited by Mandela to sit on the Constitutional Court, which abolished the death penalty and forced Parliament to legalise LGBT marriage.

In Ghent, the now 8I-year-old freedom fighter nuances the pessimistic news coming out of South Africa. 'A lot is going wrong in South Africa. But what gives me hope is that people can speak their minds. Our democracy works. Our institutions work, and not just the courts and tribunals. Recently we had elections, and they were free and fair. And yes, the ANC lost the elections. But that is in fact the best evidence that our democracy works.'

\section{The conviction of President Jacob Zuma}

Jacob Zuma, the president of South Africa, had his private estate in Nkandla renovated, in part using taxpayers' money, much to the annoyance of citizens, the opposition and now also the judiciary. Like his predecessor Thabo Mbeki, JZ was often at odds with the law. Albie Sachs: 'Just like Thabo Mbeki, who is a good friend of mine by the way, Jacob Zuma has had a hard time with the justice system, although he eventually accepts the decisions made. Mbeki was also often unhappy with decisions of the Constitutional Court, but he 
did accept that our rulings were binding and acted accordingly. As a judge, I have never experienced pressure from the executive or received any threats. However, a general political statement has been made; we were once called counter-revolutionaries by the general secretary of the ANC, but he has not stirred the issue since.

Sometimes as a sitting judge you can feel very lonely. Nowadays, however, courts are popular in South Africa. This has a lot to do with Nkandla, the private home of president Jacob Zuma. A president may use taxpayers' money for security upgrades to his house, but some projects were simply not justifiable. His swimming pool was supposedly intended for extinguishing fires. So why are there blue tiles on the bottom? He also had a chicken run built at public expense, arguing that if someone broke in, the chickens' clucking would sound the alarm. Needless to say no justification was offered for the amphitheatre. Our Public Protector eventually decided that the president should pay back a reasonable sum to the government. The parliament, however, dominated as it was by his party, the ANC, set up a committee that recognised the ruling as serious, but came to the conclusion that it was not binding. It was simply a recommendation, so to speak. The opposition party Economic Freedom Fighters, who had always criticised our institutions, went to the Constitutional Court and its ruling was clear. The report of the Public Protector was not a recommendation, but a legally binding ruling. In the end, Zuma accepted that he had to repay the money.

A few days after the verdict I was at Johannesburg airport and a large black man blocked my way. 'Thank you! Thank you!' he shouted. 'I have been away from the Court for a long time', I said, 'I have nothing to do with this'. He did not even say why he expressed his gratitude, he assumed that I knew why.

My impression is, and now I'm speaking as a citizen, not as an ex-judge, that there is huge support for the stands made by the Court. That is why I would say that our judges are not exceptionally courageous, they are just doing their job. They do their duty as best they can and I feel very proud of the people who are now sitting on the bench.'

\section{Disappointment over Nelson Mandela}

Since Nelson Mandela died in December 2013, more and more black South Africans believe that when Apartheid fell this black freedom fighter made too many concessions to the "white" minority in South Africa, a minority that still dominates the country, economically at least. On occasion South Africans even refer with envy to Zimbabwe, where white farmers have been forcibly 'expropriated'.

Albie Sachs: 'The best way to counter this is to tell the story of the past. You have to make a country fairer, but in an honest way.

In my opinion, the ANC can boast of four important things. First of all, the movement was the driving force behind the ending of Apartheid. It did not do this alone, of course, but it was central. Secondly, it was instrumental in the creation of the new democracy, in fact it was the key to that achievement.

As the Constitutional Court, we had to introduce elements of sharing \& caring. We had to abolish the death penalty and corporal punishment. We had to facilitate land reform and 
improved access to education. We had to prevent people from being unlawfully driven out of their homes or off their land. A very important case at the Court was ensuring that people with HIV had access to medicines. We also had to improve the lot of African women in traditional households so that they have a fair share of ownership in the family and in decision-making.

The transition to democracy was an extraordinary story, but it did not happen by itself. Until that change, South Africa had been an unjust and cruel country. The new constitution was not intended to maintain the status quo, to protect what already existed. It had to be emancipatory, bring about real change.

There were breakdowns, crises, murders. Mandela played a remarkable role, but he did not do it alone. There were large teams working hard and a lot of people were involved at street level.

We had to ensure the implementation of the Constitution and help the transformation of the country. Our rulings have ensured that those rights were actually implemented, as the Constitution, in our view, asked of us.

Thirdly, and this is often underestimated, the ANC was central to the reconstruction of South African institutions. Under Apartheid, there were no fewer than I6 different education administrations. These had to be united into one department. The province boundaries were redrawn. Soldiers who had faced off against each other were merged into one force. That is quite extraordinary. And some even became commanders over others. All of this proceeded calmly. The parliament was integrated and opened up. The executive, the press and the judiciary were reformed. The ANC in particular was fundamental to these achievements.

The fourth achievement of the ANC is the creation of a democratic system in which the party itself is prepared to relinquish power. It may seem paradoxical, but the fact that they have now lost the elections, and conceded defeat, is by far the ANC's most important accomplishment.

\section{The electoral defeat of the ANC}

During the last elections in August 20I6, support for the ANC fell below the psychological 60 percent line for the first time. Never before had the party that led South Africa out of Apartheid, and had the late Nelson Mandela as its icon, won so few votes.

Albie Sachs: 'Parties come and go. Leaders come and go. Leaders become popular. Leaders lose supporters. The last elections were free and fair. And power in some of our largest cities has passed from the ANC to the opposition. The fact that the governing party relinquished power under a constitution that it had itself created, proves how vital the democratic process is, a process made possible by the efforts of the ANC is.

I received an email from someone from Congo, who has been a member of the opposition there for years. He was completely bowled over that the ANC had relinquished power! Great, right? Even though he had been a fan of the ANC for decades, he recognised that an African governing party giving up power when it loses an election, is such a rare occurrence.

Why did the ANC lose its support? That is up to the people themselves to decide. My 


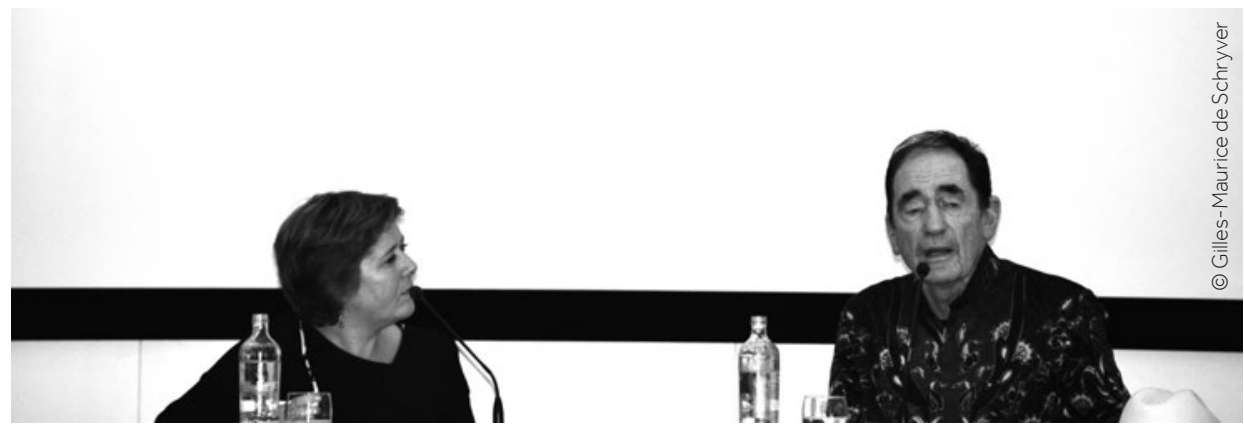

Figure 1: Eva Brems (UGent) and Albie Sachs on the 3rd Mandela Lecture, 2016.

impression is the (new) middle class in particular, which is doing reasonably well, is moving away from the ANC. The poor are still big ANC supporters, not only because of the struggle, but also because their lives have actually improved.

South Africa has made good progress in all these years. From a state of starvation we have progressed to a point of being "just hungry". People have bread on the table, but not enough. Our welfare benefits are well developed: one in three receives benefits, the poor, children, but also the elderly and single people. Ninety percent of the population has access to electricity, and a similar proportion to clean water.

One area in which spectacular progress has been made is housing. 3.5 million houses, brick houses with water, sewerage and electricity, were given away free of charge to people who had previously lived in slums. So about a quarter of the population has been moved into better accommodation. This is impressive by international standards, and I think it explains why the poor are still fervent supporters of the ANC.

What is shocking is the extent to which the super-rich have become even wealthier. And what people really can't stand is corruption, they get very angry about it. For example, when the news emerged that certain wealthy individuals are able to nominate candidates for important positions in the government or other institutions.

The fight for better internal democracy within the ANC will be an important issue in the coming years. I do not know how that will turn out. The next elections are in less than that year.

\section{Slide to the right}

Crime rates in South Africa are extremely high, and some voices are calling for the reintroduction of the death penalty. Will society once again slide to the right, become more authoritarian? In other parts of Africa, there seems to be a growing desire for strong leaders. Albie Sachs: 'Our first major case in the Constitutional Court was the abolition of the death penalty. The new constitution had not yet abolished the death penalty, although it did not allow it. Mandela and the ANC wanted to get rid of it, while de Klerk could not imagine a country that did not execute its citizens. So it was left to the Constitutional Court and we immediately decided that it was not compatible with the values in our Bill of Rights. 
In terms of the death penalty, the verdict was unanimous, but we could also express our own opinions as members of the Court. The Constitutional Court strives for consensus, but also publishes the opinions of the individual sitting judges. This makes your judgments much richer, much more sophisticated than if the Court produces only one text that is supported by the unanimity of the Court.

There was one stunning opinion, which came down to the following: the death penalty is such a severe, irreversible punishment. A mistake cannot be undone. The discretionary power of a judge is incompatible with such a punishment. Moreover, it has never been proven that the death penalty is better as a deterrent compared to the knowledge that you will be behind bars for a long time.

My opinion was and is that the state should not kill its citizens. As another colleague said, when the state kills someone, you do not punish the crime, you repeat the crime.

And, I do not see a typical African tendency towards anti-democratic leadership. It is dangerous to generalise. There are many countries about which we hear very little in the news, such as Mauritius or Namibia, two countries where there are regular elections and fairly open societies. What is becoming clear, however, is that military regimes, with the exception of Egypt, are increasingly being rejected in spite of the fact that the African Union is simply not strong enough to take a stand against them.

In the case of South Africa, I do not see a shift towards autocratic leadership. In my opinion, much depends on the economy, history and population of a country. In South Africa, citizens are very politically aware. Nor do we have a strong army, something that as a patriot I am happy about. The army simply cannot seize power. In fact, South Africa is a very diverse country, with a strong economy, and it is also highly industrialised, and so requires very sophisticated management. Finally, dialogue and consensus are deeply rooted in the culture, which often leads to more democracy and openness.

\section{The violent student protests}

Since lastyear, many students in South Africa have protested en masse against the planned increase in enrolment fees. The protest has become increasingly bitter with students devastating the patrimony and police shooting at demonstrators with rubber bullets.

Albie Sachs: 'I find the \#FeesMustFall movement astonishing. Suddenly, there was an outburst of idealism, passion and dedication, that had nothing to do with political calculation and the question of what's in it for me? The movement talked about very complex issues that were conveniently referred to as decolonization, and about very concrete problems, such as the working conditions of campus workers or the mountain of debt that haunt many students.

One in three students in South Africa is too poor to be able to pay for books and to afford a square meal. Some students have to spend the night in the library, because they don't have the fare for the bus or because their township is too far away. And all this while many of their fellow students can fly to London or Antwerp, and so on.

It's not always a racial difference. There are black students with wealthy parents, who have $\mathrm{PhDs}$ from Oxford and travel the world. In the middle you find the group, about 
one third of the students, who have too little money to pay for their studies themselves, students whose families work tirelessly to cover the costs. Another problem is that if the fees are not paid on time, students do not receive their credits.

In the beginning there was overwhelming support for the movement among students and among the public, but that support has become divided. The vast majority, $75 \%$ or more, are satisfied with what has been achieved and want to consolidate their gains. They say: Let's get back to studying now. We don't want a small group of students disrupting our lessons and exams and, and we certainly don't want them burning our books.

However, a small minority thinks that no one should pay enrolment fees. The other side wonders why those students who are comfortably off shouldn't pay more, as they can afford it anyway.

I do not know how it will turn out, but I am hopeful. Two months ago I spoke to about two hundred female students, born free's of all colours, and I was so impressed. I spoke to a young woman who used such exquisite, thoughtful language, while trying to prove that she was not free. So how come you speak as a free person, I said. Listen to yourself anyway. You contradict yourself. Your mind is as free as it can be!

This is the new generation that will produce thoughtful, mature leaders. Their career sometimes resembles that of Nelson Mandela. In the white communists, he initially saw only "the other race", the enemy, but they would later become his friends. During his struggle, he had to admit that it was often whites who gave him weapons, who gave him shelter when he had to go into hiding again. And at the same time it was often blacks who spied or tortured for the Apartheid regime.

Even these students have seen that it makes sense to have fellow students who are white participate in the cause. Not only because the police are less likely to quickly overreact, but also because those students also want to make an important point. It remains to be seen how things will go, but I love their energy. I like their idealism. I love their thoughtfulness. I worry when they set buildings on fire. That is terrible, you can't turn something like that back. 


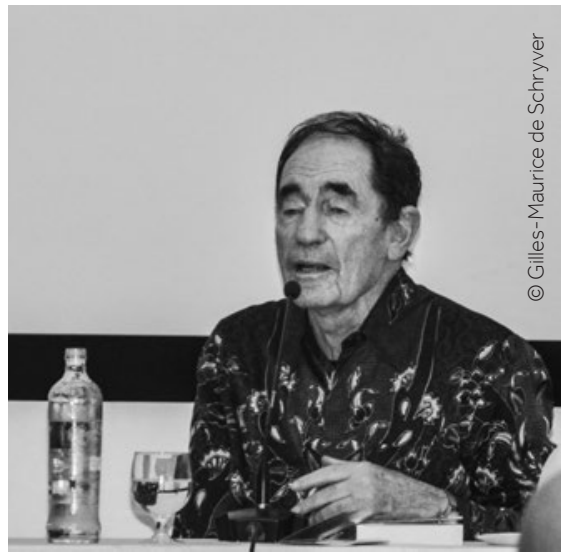

\section{Sachs, the man with the pink glasses}

In a strange way, I have only really become optimistic since they blew me up, in I988. That's the day every freedom fighter fears. What if they come to get me? Will I be brave? Will I survive it? They tried to kill me and I survived! In one fell swoop I was free of all the grief, the lack of sleep and the interrogations.

I consider myself the most privileged person in the world. I have been able to go to school, to university, I was able to become what I wanted to be. Eventually I became a freedom fighter, of my own free will. Even in prison I was still privileged. I remember one of the white prison guards saying to a black prison guard: Bring some water to the boss. I hated to be called a boss. After the attack, it was my story made the front pages and the television news, but so many people were blown up. I was in the New York Times, just because a white body turned out to be more important than a black one. I got so many opportunities after that as well. How many law students can say that they co-wrote the constitution of their own country? Well then! And not just writing a few amendments, but the actual basis for them. How exceptional is that. And then to be allowed to sit on the Constitutional Court!

I have lived a joyful life, not a life that has been exclusively one of sacrifice. I was a freedom fighter, I knew the risks and I am glad that I have been able to see the things for which we fought become a reality. 